\title{
ANALISIS HUBUNGAN FAKTOR DEMOGRAFI, FAKTOR PENYAKIT, DAN FAKTOR PSIKOLOGIS DENGAN MAKNA SPIRITUAL PENGALAMAN SAKIT
}

\author{
Nurhayati ${ }^{1}$, Rohman Azzam², Mustikasari ${ }^{3}$ \\ 1,2Universitas Muhammadiyah Jakarta \\ ${ }^{3}$ Fakultas Ilmu Keperawatan Universitas Indonesia
}

Corresponding Author : dean.nur@yahoo.com,nurhayatideanur@gmail.com

\begin{abstract}
The prevalence of HIV/AIDS is increasing in almost all over the world, the most incidence is in productive age. High community stigma and discrimination, has a negative impact on people living with HIV/AIDS (PLWHA) and the wider life. Objective: Identify the relationship between demographic factors (age, gender, latest education, occupation, religion, economic status, marital status), disease factors (initial diagnosis, opportunistic infections, medication adherence), and psychological factors (anxiety and depression) with meaning, spiritual experience of illness in PLHIV in East Jakarta. This study used a cross sectional study design with consecutive sampling involving 225 respondents at the Bhayangkara Hospital Level I R. Said Sukanto, Jakarta. The independent $t$ test obtained the age factor with a $p$ value of 0.043, meaning that there was a relationship between age and the spiritual meaning of the experience of illness. Chi square test on the factors of gender, recent education, employment, religion, economic status, marital status, early diagnosis, opportunistic infections, adherence to taking medication, anxiety and depression obtained p value> 0.05 means that there is no relationship between these factors and meaning, spiritual experience of illness. Opportunistic infection is a dominant factor related to the spiritual meaning of the experience of illness. There is a relationship between age and the spiritual meaning of the experience of illness, and opportunistic infections are the dominant factor related to the spiritual meaning of the experience of pain. Suggestion: It is necessary to do further research based on initial diagnosis or duration of HIV infection.
\end{abstract}

Keywords: Demography, Spiritual Meaning, PLWHA, Disease, Psychology

\section{PENDAHULUAN}

Stigma dan diskriminasi masyarakat terhadap orang dengan HIV/AIDS (ODHA) berkembang secara luas, berakibat memburuknya kondisi ODHA baik fisik maupun psikologis (Sarkar, Karmakar, Dasgupta, \& Saha, 2019). Hal ini berdampak pada perilaku ODHA yang menyembunyikan status HIV (Mahaendriningtiyastuti, Erna Rahma Yani, 2018), takut untuk melakukan test HIV, dan menunda pengobatan (Wicaksono, Fitrikasari, Sofro, \& Peni, 2018). Banyak ODHA menginternalisasi stigma terhadap dirinya, menarik diri dari interaksi social (Syahrina \& Pranata, 2018) dan menganggap sakit HIV yang 
dideritanya merupakan kondisi negatif, yang dimanifestasikan dalam bentuk perilaku negatif (Purwandari, Nila, Johan, \& Sujianto, 2019). Hal ini sejalan dengan penelitian (Lin, Dhaliwal, Kong, Chan, \& Tan, 2017) di Singapura bahwa ODHA yang memaknai sakit negatif cenderung menarik diri dari kehidupan sosial, dan merasa malu yang berlebihan.

Tahun 2018 terdapat 37,9 juta orang di dunia terinfeksi HIV, 770.000 orang meninggal (UNAIDS, 2019). Di Asia Pasifik 5,9 juta orang, 200.000 orang meninggal. Di Indonesia tahun 2017 terdapat 27.975 orang terinfeksi HIV dan 9.280 AIDS (Kemenkes RI, 2018). Indonesia menempati urutan ke-3 tertinggi di Asia Pasifik setelah Afghanistan dan Bangladesh (UNAIDS, 2019). Provinsi DKI Jakarta urutan kedua setelah Provinsi Jawa Timur untuk kasus HIVdan urutan ke-6 dari 34 provinsi yang ada di Indonesia untuk kasus AIDS. Jakarta Timur menempati urutan ke-2 setelah Jakarta Pusat (Kemenkes RI, 2018).

Dalam suasana hati yang sedih, takut, dan cemas akan kematian, religuisitas dan spiritualitas menjadi pegangan hidup, praktek keagamaan menjadi akitivitas dalam keseharian (Andrianto1, Mendrofa, \& Muin, 2019). Hal ini merupakan langkah mendekatkan diri kepada Tuhan yang berdampak pada pemaknaan pengalaman sakit positif (Prasojo, 2017).

Banyak faktor yang berpengaruh terhadap kemampuan ODHA dalam menemukan makna spiritual pengalaman sakit dan dirasa perlu melakukan study literature tentang "Bagaimana hubungan faktor demografi (usia, jenis kelamin, pendidikan terakhir, pekerjaan, agama, status ekonomi, status perkawinan), faktor penyakit (awal diagnosa, infeksi oportunistik dan kepatuhan minum obat), dan faktor psikologis (cemas dan depresi) dengan kemampuan menemukan makna spiritual pengalaman sakit?

Tujuan dari penelitian ini yaitu teridentifikasi hubungan factor demografi, faktor penyakit, factor psikologi dan melakukan analisis faktor-faktor tersebut dengan kemampuan menemukan makna spiritual pengalaman sakit.

\section{METODE}

Penelitian ini menggunakan rancangan deskriptif analitik dengan pendekatan cross sectional study. Pengambilan data dilakukan secara online melalui google formulir. Kuisioner yang digunakan terdiri dari kuisioner karakteristik demografi, Moresky Medication Adherence Scalae (MMAS-8) (Nasasira et al., 2018), Beck Anxiety Inventoty (BAI) ( Beck, Epstein, Brown \& Steer 1988 dalam (Meliala, 2018), Beck Depression Inventory II (BDI) (Guerra-pe, Cano-vindel, Adria, \& Herrera-martı, 2018) dan makna spiritual pengalaman sakit (dikembangkan oleh peneliti berdasarkan penelitian terkait). Kuisioner demografi terdiri dari 9 (Sembilan) item pertanyaan, 7 (tujuh) pertanyaan karakteristik responden, yaitu untuk mengetahui usia, jenis kelamin, pendidikan terakhir, pekerjaan, agama status ekonomi, status perkawinan dan 2 (dua) pertanyaan terkait penyakit yaitu 
mulai terdiagnosa HIV dan infeksi oportunistik. Kuisioner MMAS-8 terdiri dari 8 pernyataan tentang kepatuhan minum obat, BAI dan BDI masing-masing terdiri dari 21 pernyataan terkait cemas dan depresi, dan makna spiritualitas terdiri dari 17 item pertanyaan terkait makna spiritualitas terhadap pengalaman sakit yang di adop berdasarkan pendapat dari beberapa ahli.

Hasil uji validitas dan reliabilitas MMAS-8, BAI, BDI, dan makna spiritual semua item pertanyaan mempunyai nilai $r$ hasil $>r$ tabel $(0,361)$, artinya semua pernyataan dinyatakan valid secara statistik, dengan nilai cronbach alpha 0,96 (MMAS-8), 0,918 (BAI), 0,929 (BDI), dan 0,987 (Makna spiritual), artinya instrument dinyataka reliabel.

\section{Variabel Penelitian}

Variabel dependen pada penelitian ini adalah makna spiritual pengalaman sakit dan variabel independen adalah faktor demografi (usia, jenis kelamin, pendidikan terakhir, pekerjaan, agama, status ekonomi, status perkawinan), faktor penyakit (awal diagnosa, infeksi oportunistik, kepatuhan minum obat), dan faktor psikologi (cemas, depresi).

\section{Populasi dan Sampel Penelitian}

Populasi dan sampel dalam penelitian ini adalah pasien HIV Poliklinik Matahari Rumah Sakit Bhayangkara Tingkat I Jakarta Timur. Teknik sampling yang digunakan non probability sampling, dengan consecutive sampling, jumlah sampel 225 responden, dipilih sesuai dengan kriteria inklusi yang ditetapkan yaitu; bersedia menjadi responden, mengerti Bahasa Indonesia, mengetahui status dirinya positif HIV, Usia 20 - 49 tahun dan dalam pengobatan Anti Retroviral.

\section{Tahapan Penelitian}

Setelah melalui sidang proposal, peneliti mengajukan uji etik penelitian ke Fakultas Keperawatan Universitas Muhammadiyah Jakarta (UMJ), permohonan uji etik disetujui dengan hasil : penelitian layak untuk dilakukan (SK Lolos Kaji Etik no: 0458/F-9-UMJ/IV/2020).

Mengajukan permohonan izin penelitian kepada pimpinan rumah sakit, penelitian diijinkan dengan surat (SK No: B/2670/V/2020/RS.BHAY.TK.1). Dalam proses pengumpulan data peneliti dibantu oleh 2 (dua) orang enumerator yaitu 1 (satu) orang petugas poliklinik matahari dan 1 (satu) orang petugas Lembaga Swadaya Masyarakat yang mengelola pasien HIV di Poliklinik Matahari. Data diolah dan dikelompokkan berdasarkan analisis univariat, bivariate dan multivariate. 
Jurnal Ilmu Keperawatan Medikal Bedah Vol. 4 (1), Bulan Mei Tahun 2021, Hal. 25-41 ISSN 2338-2058 (print), ISSN 2621-2986 (online)

HASIL

Analisis Univariat

Table. 1

Distribusi Frekuensi Responden Berdasarkan Faktor Demografi (Usia) di Rumah Sakit Bhayangkara TK I R. Said Sukanto, Juli 2020 ( $n=225)$

\begin{tabular}{cccc}
\hline Variabel & $\begin{array}{c}\text { Mean } \\
\text { Median }\end{array}$ & $\begin{array}{c}\text { Standar } \\
\text { Deviasi }\end{array}$ & $\begin{array}{c}\text { Minimal } \\
\text { Maximal }\end{array}$ \\
\hline Usia & 34,84 & & 21 \\
& 34,00 & 7,867 & 49 \\
\hline
\end{tabular}

Tabel 1 menunjukkan bahwa rata-rata usia responden 34,84 tahun, termuda 21 tahun dan usia tertua 49 tahun.

Tabel. 2

Distribusi Frekuensi Responden Berdasarkan Faktor Demografi (Jenis Kelamin, Pendidikan Terakhir, Pekerjaan, Agama, Status Ekonomi, Status Perkawinan) di Rumah Sakit Bhayangkara TK I R. Said Sukanto, Juli 2020 ( $n=225)$

\begin{tabular}{|c|c|c|}
\hline Variabel & Jumlah & Persentase (\%) \\
\hline \multicolumn{3}{|l|}{ Jenis Kelamin: } \\
\hline Laki-laki & 167 & 74,2 \\
\hline Perempuan & 58 & 25,8 \\
\hline \multicolumn{3}{|l|}{ Pendidikan Terakhir: } \\
\hline Tidak Sekolah & 1 & 0,4 \\
\hline SD & 9 & 4 \\
\hline SMP & 21 & 9,3 \\
\hline SMA & 124 & 55,1 \\
\hline PT & 70 & 31,1 \\
\hline \multicolumn{3}{|l|}{ Pekerjaan: } \\
\hline Tidak Bekerja & 59 & 26,2 \\
\hline Petani & - & - \\
\hline Buruh/Karyawanm Swasta & 101 & 44,9 \\
\hline Wiraswasta/Dagang & 44 & 19,6 \\
\hline PNS/TNI/POLRI & 21 & 9,3 \\
\hline \multicolumn{3}{|l|}{ Agama: } \\
\hline Islam & 208 & 92,4 \\
\hline Kristen & 14 & 6,2 \\
\hline Protestan & 2 & 0,9 \\
\hline Hindu & - & - \\
\hline Budha & 1 & 0,4 \\
\hline Kong $\mathrm{Hu} \mathrm{Cu}$ & - & - \\
\hline \multicolumn{3}{|l|}{ Status Ekonomi: } \\
\hline Pendapatan $\leq 4$ juta/bulan & 121 & 53,8 \\
\hline Penapatan $>4$ juta/bulan & 92 & 40,9 \\
\hline Lainnya & 12 & 5,3 \\
\hline \multicolumn{3}{|l|}{ Status perkawinan: } \\
\hline Belum/tidak Menikah & - & - \\
\hline Menikah & 187 & 83,1 \\
\hline Janda/Duda & 38 & 16,9 \\
\hline
\end{tabular}

Tabel.2 menunjukkan bahwa mayoritas responden berjenis kelamin lakilaki yaitu 167 orang (74,2\%), pendidikan terakhir paling banyak pendidikan SMA 124 orang (55,1\%), bekerja sebagai buruh/karyawan swasta yaitu 101 orang (44,9\%), menganut agama islam 208 orang (92,4\%), pendapatan kurang 
Jurnal Ilmu Keperawatan Medikal Bedah Vol. 4 (1), Bulan Mei Tahun 2021, Hal. 25-41 ISSN 2338-2058 (print), ISSN 2621-2986 (online)

dari Rp. 4 juta/bulan 121 orang $(53,8 \%)$, dan status menikah 187 orang $(83,1 \%)$.

Tabel.3

Distribusi Frekuensi Responden Berdasarkan Faktor Penyakit (Awal Diagnosa) di Rumah Sakit Bhayangkara TK I R. Said Sukanto, Juli 2020 (n=225)

\begin{tabular}{cccc}
\hline Variabel & $\begin{array}{c}\text { Mean } \\
\text { Median }\end{array}$ & Standar Deviasi & $\begin{array}{c}\text { Minimal } \\
\text { Maximal }\end{array}$ \\
\hline Awal Diagnosa & 4,49 & 4,306 & 0 \\
& 3,00 & & 27 \\
\hline
\end{tabular}

Tabel.3 menunjukkan bahwa berdasarkan awal diagnosa atau lamanya terinfeksi virus HIV didapatkan rata-rata pasien sudah terdiagnosa HIV 4,49 tahun, terpendek 0 tahun dan terlama 27 tahun.

Tabel. 4

Distribusi Frekuensi Responden Berdasarkan Faktor Penyakit (Infeksi Oportunistik dan Kepatuhan Minum Obat) di Rumah Sakit Bhayangkara TK I R. Said Sukanto, Juli 2020 ( $n=225)$

\begin{tabular}{lcc}
\hline \multicolumn{1}{c}{ Variabel } & Jumlah & Persentase (\%) \\
\hline Infeksi Oportunistik: & & \\
Tidak ada & 137 & 60,9 \\
Ada & 88 & 39,1 \\
\hline Kepatuhan Minum Obat: & & \\
Rendah & 54 & 24 \\
Sedang & 77 & 34,2 \\
Tinggi & 94 & 41,8 \\
\hline
\end{tabular}

Tabel. 4 menunjukkan bahwa kejadian infeksi oportunistik, sebagian besar, 137 orang $(60,9 \%)$ responden tidak disertai infeksi opportunistik, dan 88 orang $(39,1 \%)$ dengan gejala infksi opportunistik. Berdasarkan tingkat kepatuhan minum obat ARV, yaiu 94 orang $(41,8 \%)$ mempunyai tingkat kepatuhan minum obat yang tinggi, 77 orang (34,2\%), tingkat kepatuhan minum obat sedang, dan 54 orang (24\%), tingkat kepatuhan minum obat yang rendah.

Tabel.5

Distribusi Frekuensi Responden Berdasarkan Faktor Psikologis (Cemas dan Depresi) di Rumah Sakit Bhayangkara TK I R. Said Sukanto, Juli $2020(n=225)$

\begin{tabular}{|c|c|c|}
\hline Variabel & Jumlah & Persentase (\%) \\
\hline \multicolumn{3}{|l|}{ Cemas: } \\
\hline Ringan & 200 & 88,9 \\
\hline Sedang & 22 & 9,8 \\
\hline Berat & 3 & 1,3 \\
\hline \multicolumn{3}{|l|}{ Depresi: } \\
\hline Ringan & 192 & 85,3 \\
\hline Sedang & 31 & 13,8 \\
\hline Berat & 2 & 0,9 \\
\hline
\end{tabular}

Tabel.5 menunjukkan bahwa sebagian besar responden mengalami cemas ringan yaitu 200 orang (88,9\%), cemas sedang 22 orang $(9,8 \%)$, dan cemas berat 3 orang (1,3\%). Proporsi responden berdasarkan tingkat depresi sebagian besar responden mengalami depresi ringan yaitu 192 orang (85,3\%), depresi sedang 31 orang $(13,8 \%)$, dan 2 orang $(0,9 \%)$ responden mengalami depresi berat. 
Jurnal Ilmu Keperawatan Medikal Bedah Vol. 4 (1), Bulan Mei Tahun 2021, Hal. 25-41 ISSN 2338-2058 (print), ISSN 2621-2986 (online)

Tabel. 6

Distribusi Frekuensi Responden Berdasarkan Makna Spiritual di Rumah Sakit Bhayangkara TK I R. Said Sukanto, Juli $2020(n=225)$

\begin{tabular}{lcc}
\hline \multicolumn{1}{c}{ Variabel } & Jumlah & Persentase (\%) \\
\hline Makna Spiritual pengalaman Sakit: & & \\
Negatif & 66 & 29,3 \\
Positif & 159 & 70,7 \\
\hline
\end{tabular}

Tabel. 6 menunjukkan perbedaan yang sangat mencolok antara ODHA yang memaknai pengalaman sakit positif dan ODHA yang memaknai pengalaman sakit secara negatif, yaitu sebanyak 159 orang $(70,7 \%)$ ODHA memaknai pengalaman sakit positif dan 66 orang $(29,3 \%)$ ODHA memaknai pengalaman sakit negatif.

\section{Analisis Bivariate}

Tabel.7

Hubungan Faktor Demografi (Usia) dengan Makna Spiritual Pengalaman Sakit di Rumah Sakit Bhayangkara TK I R. Said Sukanto, Juli 2020 ( $n=225)$

\begin{tabular}{|c|c|c|c|c|c|c|}
\hline Variabel & $\begin{array}{c}\text { Makna } \\
\text { Spiritual }\end{array}$ & Mean & SD & SE & $\begin{array}{c}P \\
\text { value }\end{array}$ & $\mathbf{N}$ \\
\hline Usia & $\begin{array}{l}\text { Negatif } \\
\text { Positif }\end{array}$ & $\begin{array}{c}33,0 \\
35,52\end{array}$ & $\begin{array}{l}7,730 \\
7,846\end{array}$ & $\begin{array}{l}0,952 \\
0,622\end{array}$ & 0,043 & $\begin{array}{c}66 \\
159\end{array}$ \\
\hline
\end{tabular}

Tabel.7 menunjukkan bahwa hasil uji beda dua mean $t$ independent diperoleh p value 0,043 artinya pada alpha 5\% dapat disimpulkan bahwa ada hubungan antara usia dengan kemampuan menemukan makna spiritual pengalaman sakit.

Tabel.8

Hubungan Faktor Penyakit (Awal Diagnosa) dengan Makna Spiritual Pengalaman Sakit di Rumah Sakit Bhayangkara TK I R. Said Sukanto, Juli 2020 ( $n=225)$

\begin{tabular}{ccccccc}
\hline Variabel & $\begin{array}{c}\text { Makna } \\
\text { Spiritual }\end{array}$ & Mean & SD & SE & P value & N \\
& & & & & \\
\hline Awal Diagnosa & Negatif & 4,79 & 4,904 & 0,604 & & 66 \\
& Positif & 4,36 & 4,043 & 0,321 & 0,503 & 159
\end{tabular}

Hasil uji beda dua mean $t$ independent pada tabel 8 diperoleh $\mathrm{p}$ value 0,503 yang artinya pada alpha 5\% tidak ada perbedaan yang bermakna rata-rata lama terdiagnosa HIV antara responden yang menemukan makna spiritual pengalaman sakit positif dengan responden yang menemukan makna spiritual pengalaman sakit negatif.

Tabel.9

Hubungan Faktor Penyaki (Infeksi Oportunistik dan Kepatuhan Minum Obat) dengan Makna Spiritual Pengalaman Sakit di Rumah Sakit Bhayangkara TK I R. Said Sukanto, Juli 2020 (n=225)

\begin{tabular}{|c|c|c|c|c|c|c|c|c|}
\hline \multirow{3}{*}{\multicolumn{2}{|c|}{ Kategori }} & \multicolumn{4}{|c|}{ Makna Spiritual pengalaman Sakit } & \multirow{3}{*}{$\Sigma$} & \multirow{3}{*}{$\begin{array}{c}\mathbf{P} \\
\text { Value }\end{array}$} & \multirow{3}{*}{ OR $95 \% \mathrm{Cl}$} \\
\hline & & \multicolumn{2}{|c|}{ Negatif } & \multicolumn{2}{|c|}{ Positif } & & & \\
\hline & & $\mathbf{N}$ & $\%$ & $\mathbf{N}$ & $\%$ & & & \\
\hline \multicolumn{9}{|c|}{ Infeksi Oportunities: } \\
\hline \multirow{2}{*}{-} & Tidak ada & 47 & 34,3 & 90 & 65,7 & 137 & 0,06 & 1,9 \\
\hline & Ada & 19 & 21,6 & 69 & 78,4 & 88 & & \\
\hline \multicolumn{2}{|c|}{ Kepatuhan Minum Obat: } & 16 & 29,6 & 38 & 70,4 & 54 & 0,77 & 1,11 \\
\hline \multirow{2}{*}{\multicolumn{2}{|c|}{$\begin{array}{ll}- & \text { Rendah } \\
- & \text { Sedang } \\
- & \text { Tinggi }\end{array}$}} & 20 & 26,0 & 57 & 74,0 & 77 & & \\
\hline & & 30 & 31,9 & 64 & 68,1 & 94 & $\begin{array}{c}0,4 \\
P\end{array}$ & $\begin{array}{c}1,34 \\
\mathrm{P}\end{array}$ \\
\hline
\end{tabular}



ISSN 2338-2058 (print), ISSN 2621-2986 (online)

Hasil uji Chi-square pada table 9 diperoleh p value 0,06, artinya tidak ada hubungan antara infeksi oportunistik dengan kemampuan menemukan makna spiritual pengalaman sakit, dengan Odds ratio 1,9 artinya responden yang sudah terinfeksi oportunistik memiliki peluang sebanyak 1,9 kali untuk menemukan makna spiritual pengalaman sakit yang positif dibanding responden yang tidak terinfeksi oportunistik.

Hasil uji regresi logistik sederhana (dummy variabel) diperoleh p value 0,77 untuk kelompok responden yang memiliki kepatuhan rendah dan kepatuhan tinggi, dan $\mathrm{p}$ value 0,4 untuk kelompok responden yang memiliki kepatuhan sedang dan kepatuhan tinggi, artinya tidak ada hubungan antara tingkat kepatuhan rendah, sedang dan tinggi dengan kemampuan menemukan makna spiritual pengalaman sakit.

Tabel.10

Hubungan Faktor Demografi (Jenis Kelamin, Pendidikan Terakhir, Pekerjaan, Agama, Status Ekonomi dan Status Perkawinan) dengan Makna Spiritual Pengalaman Sakit di Rumah Sakit Bhayangkara TK I R. Said Sukanto, Juli 2020 ( $n=225)$

\begin{tabular}{|c|c|c|c|c|c|c|c|}
\hline \multirow{3}{*}{ Kategori } & \multicolumn{4}{|c|}{ Makna Spiritual pengalaman Sakit } & \multirow{3}{*}{$\Sigma$} & \multirow{3}{*}{$\begin{array}{c}\mathrm{P} \\
\text { Value }\end{array}$} & \multirow{3}{*}{ OR $95 \% \mathrm{Cl}$} \\
\hline & \multicolumn{2}{|c|}{ Negatif } & \multicolumn{2}{|c|}{ Positif } & & & \\
\hline & $\mathrm{N}$ & $\%$ & $\mathrm{~N}$ & $\%$ & & & \\
\hline \multicolumn{8}{|l|}{ Jenis Kelamin: } \\
\hline \multirow{2}{*}{$\begin{array}{l}\text { Laki-laki } \\
\text { Perempuan }\end{array}$} & 55 & 32,9 & 112 & 67,1 & 167 & 0,07 & 2,1 \\
\hline & 11 & 19 & 47 & 81 & 58 & & \\
\hline \multicolumn{8}{|l|}{ Pendidikan Terakhir: } \\
\hline \multirow{3}{*}{$\begin{array}{l}\text { Pendidikan Dasar } \\
\text { Pendidikan } \\
\text { Menengah } \\
\text { Pendidikan Tinggi }\end{array}$} & 3 & 30 & 7 & 70 & 10 & 0,93 & 0,93 \\
\hline & 43 & 29,7 & 102 & 70,3 & 145 & 0.87 & 0.95 \\
\hline & 20 & 28,6 & 50 & 71,4 & 70 & $P$ & $\mathrm{P}$ \\
\hline \multicolumn{8}{|l|}{ Pekerjaan: } \\
\hline Tidak bekerja & 17 & 28,8 & 42 & 71,2 & 59 & $P$ & $P$ \\
\hline \multicolumn{8}{|l|}{ Buruh/Karyawan swasta } \\
\hline + Wiraswasta/dagang & 46 & 31,7 & 99 & 68,3 & 145 & 0,68 & 0,87 \\
\hline PNS/TNI/POLRI & 3 & 14,3 & 18 & 85,7 & 21 & 0,2 & 2,43 \\
\hline \multicolumn{8}{|l|}{ Agama: } \\
\hline Islam & 63 & 30,3 & 145 & 69,7 & 208 & 0,41 & 2,03 \\
\hline Non Islam & 3 & 17,6 & 14 & 82,4 & 17 & & \\
\hline \multicolumn{8}{|l|}{ Status Ekonomi: } \\
\hline$\leq 4$ Juta/bulan & 42 & 31,6 & 91 & 68,4 & 133 & 0,46 & 1,31 \\
\hline$>4$ juta /bulan & 24 & 16,1 & 68 & 73,9 & 92 & & \\
\hline \multicolumn{8}{|l|}{ Status Perkawinan: } \\
\hline Menikah & 58 & 31 & 129 & 69 & 187 & 0,30 & 1,69 \\
\hline Janda/Duda & 8 & 21,1 & 30 & 78,9 & 38 & & \\
\hline
\end{tabular}

Tabel. 10 menunjukkan bahwa hasil uji statistic chi square didapatkan tidak ada hubungan antara jenis kelamin, pendidikan terakhir, pekerjaan, agama, status ekonomi dan status perkawinan dengan makna spiritual pengalaman sakit. 
Jurnal Ilmu Keperawatan Medikal Bedah Vol. 4 (1), Bulan Mei Tahun 2021, Hal. 25-41 ISSN 2338-2058 (print), ISSN 2621-2986 (online)

Tabel.11

Hubungan Faktor Psikologis (Cemas dan Depresi) dengan Makna Spiritual Pengalaman Sakit di Rumah Sakit Bhayangkara TK I R. Said Sukanto, Juli 2020 ( $n=225)$

\begin{tabular}{|c|c|c|c|c|c|c|c|}
\hline \multirow{3}{*}{ Kategori } & \multicolumn{4}{|c|}{ Makna Spiritual Pengalaman Sakit } & \multirow{3}{*}{$\Sigma$} & \multirow{3}{*}{$\mathbf{P}$} & \multirow{3}{*}{ OR $95 \% \mathrm{Cl}$} \\
\hline & \multicolumn{2}{|c|}{ Negatif } & \multicolumn{2}{|c|}{ Positif } & & & \\
\hline & $\mathbf{N}$ & $\%$ & $\mathbf{N}$ & $\%$ & & & \\
\hline \multicolumn{8}{|l|}{ Cemas: } \\
\hline Ringan & 57 & 28,5 & 143 & 71,5 & 200 & 0,999 & 1 \\
\hline Sedang & 9 & 40,9 & 13 & 59,1 & 22 & $P$ & $P$ \\
\hline Berat & 0 & 0 & 3 & 100 & 3 & 0,23 & 1,74 \\
\hline \multicolumn{8}{|l|}{ Depresi: } \\
\hline Ringan & 54 & 28,1 & 138 & 71,9 & 192 & 0,33 & 1,48 \\
\hline Sedang & 11 & 35,5 & 20 & 64,5 & 31 & $\mathrm{P}$ & $\mathrm{P}$ \\
\hline Berat & 1 & 50 & 1 & 50 & 2 & 0,70 & 0,57 \\
\hline
\end{tabular}

Tabel 11 menjelaskan hasil uji regresi logistik sederhana (dummy variabel) diperoleh p value 0,999 untuk kelompok responden yang mengalami cemas berat dan cemas sedang, dan p value 0,23 untuk kelompok responden yang mengalami cemas ringan dan cemas sedang, artinya tidak ada hubungan antara cemas ringan, sedang dan berat dengan kemampuan menemukan makna spiritual pengalaman sakit.

\section{Analisis Multivariate}

Tabel.12

Faktor-Faktor yang Berhubungan dengan Makna Spiritual Pengalaman Sakit, di Rumah Sakit Bhayangkara TK I R. Said Sukanto, Juli $2020(n=225)$

\begin{tabular}{|c|c|c|}
\hline No & Variabel & P Value \\
\hline 1 & Usia & 0.131 \\
\hline 2 & Jenis Kelamin & 0.070 \\
\hline 3 & Pendidikan Terakhir & 0,324 \\
\hline 4 & Pekerjaan & 0,313 \\
\hline 5 & Agama & 0,430 \\
\hline 6 & Status Ekonomi & 0,843 \\
\hline 7 & Status Perkawinan & 0,855 \\
\hline 8 & Awal Diagnosa & 0,484 \\
\hline 9 & Infeksi Oportunistik & 0,084 \\
\hline 10 & Kepatuhan Minum Obat & 0,722 \\
\hline 11 & Cemas & 0,855 \\
\hline 12 & Depresi & 0,783 \\
\hline
\end{tabular}

Berdasarkan seleksi bivariate pada tabel 12 diperoleh tiga variabel yaitu variabel usia, jenis kelamin dan infeksi oportunistik yang mempunyai nilai $\mathrm{p}$ value $<0,25$, artinya ada hubungan yang bermakna antara usia, jenis kelamin dan infeksi oportunistik dengan makna spiritual pengalaman sakit. Ketiga variabel tersebut memenuhi syarat untuk menjadi kandidat pada pemodelan multivariate. 
Jurnal Ilmu Keperawatan Medikal Bedah Vol. 4 (1), Bulan Mei Tahun 2021, Hal. 25-41 ISSN 2338-2058 (print), ISSN 2621-2986 (online)

Tabel.13

Pemodelan Awal Variabel Usia, Jenis Kelamin dan Infelksi Oportunistik dengan Variabel Makna spiritual Pengalaman Sakit di RS Bhayangkara TK I R. Said Sukanto, Juli 2020, (n=225)

\begin{tabular}{lcccccccc}
\hline & & & & & P Value & & \multicolumn{2}{c}{$\mathbf{9 5 \%} \mathbf{C l}$} \\
\cline { 6 - 10 } \multicolumn{1}{c}{ Variabel } & Koefisien & S.E & Wald & df & & OR & Min & Max \\
\hline Usia & 0,025 & 0,020 & 1,556 & 1 & 0,212 & 1,025 & 0,986 & 1,067 \\
\hline Jenis Kelamin & $-0,667$ & 0,385 & 2,998 & 1 & 0,083 & 0,513 & 0,241 & 1,092 \\
\hline Infeksi Oportunistik & $-0,611$ & 0,321 & 3,618 & 1 & 0,057 & 0,543 & 0,289 & 1,019 \\
\hline
\end{tabular}

Dari hasil analisis pada tabel.13 diperoleh semua variabel mempunyai $p$ value $>0,05$ artinya bahwa variabel usia, jenis kelamin dan infeksi oportunistik tidak ada hubungan yang bermakna dengan makna spiritual pengalaman sakit, maka untuk selanjutnya dilakukan analisis kedua dengan mengeluarkan variabel yang mempunyai $p$ value paling besar yaitu variabel usia dengan $\mathrm{p}$ value 0,212 , dan kemudian membandingkan perubahan odds ratio sebelum dan sesudah Variabel usia dikeluarkan dari model.

Tabel.14

Pemodelan Kedua Variabel Jenis Kelamin dan Infelksi Oportunistik dengan Variabel Makna spiritual Pengalaman Sakit di RS Bhayangkara TK I R. Said Sukanto, Juli 2020 (n=225)

\begin{tabular}{lcccccccc}
\hline & & & & & P Value & & \multicolumn{2}{c}{$95 \%$ Cl } \\
\cline { 6 - 10 } Variabel & Koefisien & S.E & Wald & Df & & OR & Min & Max \\
\hline Jenis Kelamin & $-0,765$ & 0,376 & 4,124 & 1 & 0,042 & 0,466 & 0,223 & 0,964 \\
\hline Infeksi Oportunistik & $-0,661$ & 0,318 & 4,304 & 1 & 0,038 & 0,517 & 0,277 & 1,019 \\
\hline
\end{tabular}

Dari tablel.14 di atas sesudah dikeluarkan variabel usia tidak ada perubahan odds ratio $\geq 10 \%$ pada variabel lain, untuk itu variable usia dikeluarkan secara permanen. Pada variabel jenis kelamin dan infeksi oportunistik setelah variabel usia dikeluarkan diperoleh $\mathrm{p}$ value $<0,05$ yaitu 0,042 untuk variabel jenis kelamin dan 0,038 untuk variabel infeksi oportunistik, artinya kedua variabel tersebut ada hubungan yang bermakna dengan makna spiritual pengalaman sakit, dan variabel infeksi oportunistik mempunyai odd ratio yang lebih besar dibandingkan dengan variabel jenis kelamin artinya variabel infeksi oportunistik merupakan faktor dominan berhubungan dengan makna spiritual pengalaman sakit. Berdasarkan data tersebut, maka tabel.14 merupakan pemodelan terakhir, dan untuk tahap selanjutmya dilakukan uji interaksi antara variabel jenis kelamin dan variabel infeksi oportunistik untuk melihat interaksi dari kedua variabel tersebut.

Tabel.15

Uji Interaksi Variabel Jenis Kelamin dan Infelksi Oportunistik di RS Bhayangkara TK I R. Said Sukanto, Juli $2020(n=225)$

\begin{tabular}{lcccccccc}
\hline & & & & & P & & \multicolumn{2}{c}{$\mathbf{9 5 \%} \mathbf{~ C l}$} \\
\cline { 6 - 10 } \multicolumn{1}{c}{ Variabel } & Koefisien & S.E & Wald & df & Value & OR & Min & Max \\
\hline Jenis Kelamin & $-0,408$ & 0,426 & 0,917 & 1 & 0,338 & 0,665 & 0,289 & 1,532 \\
\hline Infeksi Oportunistik & $-0,433$ & 0,345 & 1,574 & 1 & 0,210 & 0,649 & 0,330 & 1,276 \\
\hline JK*IO & 1,656 & 1,142 & 2,102 & 1 & 0,147 & 5,239 & 0,558 & 49,168 \\
\hline
\end{tabular}

Tabel. 15 menunjukkan hasil uji interaksi antara variabel jenis kelamin dan variabel infeksi oportunistik diperoleh p value $>0,05$ yaitu 0,095 artinya tidak ada interaksi antara jenis kelamin dan infeksi oportunistik, oleh karena hasil analisis tidak ada interaksi, maka pemodelan ini valid secara statistic. 
Jurnal Ilmu Keperawatan Medikal Bedah Vol. 4 (1), Bulan Mei Tahun 2021, Hal. 25-41 ISSN 2338-2058 (print), ISSN 2621-2986 (online)

Tabel.16

Pemodelan Akhir Variabel Jenis Kelamin dan Infelksi Oportunistik dengan Variabel Makna spiritual Pengalaman Sakit di RS Bhayangkara TK I R. Said Sukanto, Juli 2020 ( $n=225)$

\begin{tabular}{lcccccccc}
\hline & & & & & & P Value & \multicolumn{2}{c}{ 95\% Cl } \\
\cline { 7 - 11 } \multicolumn{1}{c}{ Variabel } & Koefisien & S.E & Wald & df & & OR & Min & Max \\
\hline Jenis Kelamin & $-0,765$ & 0,376 & 4,124 & 1 & 0,042 & 0,466 & 0,223 & 0,964 \\
\hline Infeksi Oportunistik & $-0,661$ & 0,318 & 4,304 & 1 & 0,038 & 0,517 & 0,277 & 1,019 \\
\hline
\end{tabular}

Berdasarkan tabel 16 dapat dijelaskan bahwa analisis multivariate diperoleh faktor dominan berhubungan dengan kemampuan menemukan makna spiritual pengalaman sakit adalah variabel infeksi oportunistik karena mempunyai odds ratio yang lebih besar dibanding variabel jenis kelamin.

\section{PEMBAHASAN}

Rata-rata responden berusia 34 tahun, termuda 21 tahun dan tertua 49 tahun. Hasil uji independent t-test ada hubungan antara usia dengan makna spiritual pengalaman sakit. Pada tahapan usia ini merupakan proses yang matang dan berpengaruhnya semua nilai-nilai agama dalam aspek kehidupan, agama sebagai jalan hidup, menemukna jati diri, menentukan jalan hidup, dan mengadopsi norma yang ada disekitarnya (Sari, 2020). Sikap keberagamaan cenderung mengarah kepada tipe kepribadian masing-masing, namun kapasitas diri, pengalaman, dan lingkungan sangat berpengaruh terhadap sikap religius dan spiritual (Iswati, 2018).

Indikator agama/religi merupakan hal yang sangat dibutuhkan ketika pasien HIV berada dalam kondisi sakit, energy akan habis ketika mengalami gangguan imunitas, semangat untuk memaknai hidup positif akan berkurang. Aspek spiritual dapat meningkatkan koping, mempromosikan perilaku sehat, mengurangi depresi dan kecemasan (Amal \& Khofsoh, 2018).

Mayoritas responden berjenis kelamin laki-laki, hasil uji Chi square menunjukkan tidak ada hubungan antara jenis kelamin dengan kemampuan menemukan makna spiritual pengalaman sakit. Laki-laki lebih banyak dibanding perempuan, hal ini sejalan dengan apa yang disampaikan oleh (Saktina \& Satriyasa, 2017), (Kemenkes RI, 2018), (UNAIDS, 2019). Sarvasti (2020) menyampaikan bahwa laki-laki mempunyai tingkat keparahan, prevalensi dan patogensis infeksi yang tinggi yang disebabkan oleh virus, bakteri ataupun jamur. Struktur genomic membedakan antara laki-laki dan perempuan, laki-laki mempunyai satu kromosom X (XY) sedangkan perempuan mempunyai dua kromosom X (XX). Kromosom $\mathrm{X}$ terlibat dalam sistem imun Innate dan adaptif, mempunyai efektor yang berfungsi mengontrol proses transkripsi dan translasi untuk mengaktifkan reseptor sitokinin, mengontrol mekanisme noncoding micro ribonucleic acid (miRNA), mengandung 10\% miRNA total yang terlibat dalam ekpresi gen dengan cara menghambat translasi RNA dengan cara mencetuskan degradasi RNA. Kromosom X membawa gen imun penting termasuk Toll Like - receptor 7 (TLR-7) yang mengkode sensor pathogen, studi lain mengkonfirmasi bahwa esterogen bersifat represif terhadap perkembangan dari fase laten, dan blokade dari reseptor esterogen dapat meningkatkan reaktivasi, studi lainnya menjelaskan bahwa 
Jurnal Ilmu Keperawatan Medikal Bedah Vol. 4 (1), Bulan Mei Tahun 2021, Hal. 25-41 ISSN 2338-2058 (print), ISSN 2621-2986 (online)

reseptor esterogen diidentifikasi sebagai inhibitor potensial transkripsi HIV dalam fase laten (Aurelina, 2020). Inilah yang membuat laki-laki lebih rentan terhadap infeksi dibandingkan perempuan. Penelitian ini juga sejalan dengan penelitian (Ilham, Triliana, \& Tilaqza, 2020) menyatakan bahwa laki-laki memiliki jumlah infeksi sekunder lebih banyak, durasi rawat inap lebih lama dibanding dengan perempuan.

Mayoritas responden berpendidikan menengah (SMP dan SMA), analisis bivariate menyimpulkan tidak ada hubungan pendidikan terakhir dengan kemampuan menemukan makna spiritual pengalaman sakit. Gambaran responden memungkinkan kurangnya pengetahuan tentang penyakit HIV (Anetor, 2019). Religius dan spiritual karena kurang terpapar informasi keagamaan, serta penyerapan informasi belum optimal (Jayani \& Ruffaida, 2020). Religiusitas dan spiritualitas dapat meningkatkan kedamaian dan kebahagiaan, menumbuhkan kekuatan batin, menambah pemahaman terhadap penyakit dan penerimaan diri, meningkatkan motivasi perawatan diri, menemukan arti dan tujuan hidup, memelihara asa dan menciptakan hubungan dan rasa keterkaitan terhadap sesama, dan yang lebih penting hubungan dan keterkaitan dengan Maha Pencipta (Chaiyasit, Thong-on, Piboonrungroj, \& Kotta, 2019).

Sebagian besar responden bekerja sebagai buruh/karyawan swasta/wiraswasta/dagang. Hasil uji statistic regresi logistic sederhana menyimpulkan tidak ada hubungan antara pekerjaan dengan kemampuan menemukan makna spiritual pengalaman sakit. Peneliti berasumsi kurangnya keterikatan antara responden dengan perusahaan dan waktu kerja yang fleksible sangat memungkinkan responden menggunakan atau mengalihkan waktu untuk melakukan perilaku menyimpang yang beresiko terinfeksi HIV. Besarnya pendapatan menjadi pemicu melakukan apapun yang beresiko terinfeksi HIV. Wiraswastawan mempunyai mobilitas tinggi, sering berada di luar rumah dan berinteraksi dengan banyak orang, ini pun menjadi pemicu perilaku beresiko terinfeksi HIV, sementara buruh lebih banyak menghabiskan waktu di luar rumah, baik itu bekerja dalam shift atau paruh waktu. Waktu yang dihabiskan untuk melakukan aktivitas bahkan terabaikan, ketergantungan terhadap Tuhan pun terlupakan, segala sesuatu dipikirkan berdasarkan keduniawian tanpa menghiraukan sandaran vertikal dengan Tuhan (Saktina \& Satriyasa, 2017). Hal ini sejalan dengan penelitian (Khusnah, 2019) orang yang mempunyai spiritualitas tinggi mempunyai komitmen budaya organisasi yang tinggi dan memberi pengaruh positif terhadap kinerja pada perusahaan tempat kerja.

Mayoritas responden beragama islam, hasil uji analisis chi square menyimpulkan tidak ada hubungan antara agama dengan kemampuan menemukan makna spiritual pengalaman sakit. Religiusitas memberikan pengaruh terhadap penerimaan diri ODHA, semakin tinggi tingkat religius, semakin tinggi tingkat husnudzon kepada Sang Maha Pencipta, semakin tinggi penerimaan diri terhadap sakit yang di derita (Anwar, 2020). Andrianto et al. (2019) dalam penelitiannya menjelaskan bahwa ketika seorang muslim menjalankan praktek keagamaan dengan baik, membuat ODHA muslim menerima dirinya, pasrah 

ISSN 2338-2058 (print), ISSN 2621-2986 (online)

dengan tetap berusaha untuk sehat, selalu berbaik sangka dan berpikir positif tentang penyakit yang dideritanya. Untuk mencapai semua itu peran praktisi kesehatan sangat penting untuk membantu memulihkan, meningkatkan religiusitas dan spiritualitas ODHA (Roger \& Hatala, 2018).

Mayoritas responden berpendapatan dibawah Rp. 4 juta/bulan, hasil uji chi square menyimpulkan tidak ada hubungan antara status ekonomi dengan kemampuan menemukan makna spiritual pengalaman sakit. Ada keterkaitan antara pendidikan terakhir, pekerjaan, dan pendapatan. Pendidikan terakhir menentukan seseorang mendapatkan pekerjaan, dan pekerjaan menentukan besaran pendapatan (Krause, Pargament, \& Ironson, 2017).

Pendapatan merupakan salah satu indikator status ekonomi. Pendapatan yang tinggi membuat seseorang leluasa untuk melakukan apapun, termasuk menjadikan gaya hidup beresiko perilaku menyimpang. Pendapatan yang rendah pun menjadi pemicu terjadinya perilaku menyimpang, keadaan ekonomi dibawah rata-rata, menyebabkan seseorang mengerjakan apa saja yang mampu mendatangkan tambahan penghasilan. Petuah-petuah agama dan pesan-pesan normative tidak lagi dipedulikan, yang penting kebutuhan dapat terpenuhi tanpa memikirkan dari mana jalan mendapatkannya (Mukti et al., 2019). Sulit meyakini bahwa Tuhan Maha baik, karena minimnya sumber daya spiritual, ada keengganan untuk melakukan koping strategi spiritual (Krause et al., 2017).

Sebagian besar responden menikah, hasil analisis sttistik chi square menunjukkan tidak ada hubungan antara status perkawinan dengan kemampun menemukan makna spiritual pengalaman sakit. Banyaknya ODHA berstatus menikah disebabkan tertular dari pasangannya yang terinfeksi HIV (Saktina \& Satriyasa, 2017). Keyakinan spiritual membantu individu menciptakan ikatan emosional yang dapat meningkatkan kepuasan perkawinan, spiritualitas membantu mengenali diri sendiri, mengembangkan emosi positif dan puas dengan kehidupan yang dijalani (Kasapoğlu \& Yabanigül, 2018).

Responden rata-rata sudah terdiagnosa HIV 4,49 tahun, hasil uji statistik menunjukkan tidak ada hubungan antara awal diagnosa dengan kemampuan menemukan makna spiritual pengalaman sakit. Pada tahun pertama terdiagnosa HIV, ODHA mengalami kecemasan terhadap kematian (Widianti, 2018). Perubahan religious yang positif terjadi setelah dinyatakan positif terinfeksi HIV (Prasojo, 2017). Hasil penelitian ini juga sejalan dengan penelitian yang dilakukan oleh (Jayani \& Ruffaida, 2020), yang menyebutkan bahwa 45\% responden mengalami peningkatan spiritual positif setelah terdiagnosa HIV.

Mayoritas responden tidak mengalami kejadian infeksi oportunistik, hasil uji Chi square menyimpulkan tidak ada hubungan antara kejadian infeksi oportunistik dengan kemampuan menemukan makna spiritual pengalaman sakit. Agustin, (2018) yang menyatakan bahwa tingkat spiritualitas yang tinggi dapat membuat ODHA hidup lebih tertata dan teratur, sehingga dapat meningkatkan imunitas yang pada akhirnya meningkatkan kualitas hidup ODHA. 

ISSN 2338-2058 (print), ISSN 2621-2986 (online)

Mayoritas responden mempunyai tingkat kepatuhan minum obat tinggi, hasil uji regresi logistic sederhana menunjukkan tidak ada hubungan antara kepatuhan minum obat dengan kemampuan menemukan makna spiritual pengalaman sakit. Kepatuhan minum obat pada pada penelitian ini belumlah optimal, walaupun mayoritas tetapi proporsi tidak jauh beda dengan responden yang memiliki tingkat kepatuhan sedang dan rendah, masih ada celah untuk terjadinya resistensi ARV dan rentan terjadinya kondisi kesehatan memburuk, munculnya infeksi oportunistik bahkan kematian (Dalmida et al., 2017).

Semua ODHA mempunyai keinginan untuk mengikuti program pengobatan dengan baik, tetapi efek samping ARV membuat tidak nyaman, banyak ODHA drop out, situasi ini menjadi fenomena sebagian besar ODHA, perlu dukungan dari keluarga (Beyene et al., 2019), kelompok agama, kelompok sebaya, akses pelayanan kesehatan (Lasti, 2017). Hal ini sejalan dengan penelitian yang dilakukan oleh (Dalmida et al., 2017), menyimpulkan ada hubungan antara dukungan social dengan kepatuhan minum ART. Motivasi spiritual memberi keyakinan mendalam yang positif, proses adaptasi terhadap penyakit menyadarkan bahwa dirinya terinfeksi HIV, mewajibkan untuk patuh minum obat sebagai usaha menjaga kestabilan kesehatan (Umah \& Irawanto, 2019).

Mayoritas responden mengalami cemas dan depresi ringan, hasil uji regresi logistic menyimpulkan tidak ada hubungan antara cemas dan depresi, dengan kemampuan menemukan makna spiritual pengalaman sakit. Depresi muncul sebagai dampak stigma dan diskriminasi masyarakat yang menilai bahwa ODHA adalah manusia pendosa, sedang dihukum karena perbuatannya sehingga harus dijauhi, hal ini sangat menyulitkan ODHA untuk melakukan aktivitas yang biasa dikerjakan sebelum terinfeksi HIV, situasi ini berdampak pada psikologi ODHA, mereka merasakan penyesalan yang mendalam, marah, kecewa, bingung, putus asa, dan tidak mempunyai harapan lagi untuk masa depan. Religiusitas berperan dalam mengurangi depresi (Prasojo, 2017). Peneliti berasumsi, semakin kecil tingkat cemas dan depresi, ODHA semakin mampu menemukan makna spiritual pengalaman sakit positif dan dukungan social terutama religiusitas dan spiritualitas sangat bermanfaat dalam meminimalisir terjadinya depresi.

Hasil analisis multivariate diperoleh infeksi oportunistik merupakan faktor dominan berhubungan dengan kemampuan menemukan makna spiritual pengalaman sakit. Motivasi yang tinggi untuk berperilaku sehat, percaya diri bahwa penyakit akan sembuh bila mengikuti program pengobatan (Kim, Kim, \& Ryu, 2019) berpengaruh terhadap perilaku patuh terhadap pengobatan yang pada akhirnya dapat mengurangi kejadian infeksi oportunistik. Penyakit pernyerta/infeksi oportunistik muncul beberapa tahun setelah terinfeksi HIV, psikologis pasien semakin terguncang dan sakitpun semakin dalam dirasakan. Rasa sakit (illness) merupakan respon psikis berakibat melemahnya daya tahan tubuh sehingga mempersulit penyembuhan, pikiran dan emosi terlibat dalam proses pemaknaan diri terhadap sakit, berpengaruh terhadap kondisi fisik. Selain pengetahun dan pengalaman, keimanan terhadap Alloh SWT memberi keyakinan bahwa Alloh memberikan kesembuhan dan selalu mengambil hikmah dibalik sakit. 
Kejadian infeksi oportunistik membuat ODHA cemas dan depresi, karena infeksi oportunistik menjadi penyebab terbesar kematian pada ODHA (Yuliyanasari, 2017). Dukungan religiusitas dan spiritualtas tinggi sangat membantu dalam meningkatkan kepatuhan minum obat untuk mencegah terjadinya perburukan kondisi kesehatan ODHA (Badanta et al., 2018).

Dalam penelitian ini ditemukan sebagian besar responden beragama islam $(92,4 \%)$ dengan rata-rata 34,84 tahun, yang dapat menemukan makna spiritual pengalaman sakit positif adalah rata-rata usia 35,52 tahun, artinya di atas rata-rata responden secara keseluruhan, pada usia tersebut mayoritas menyadari bahwa hidupnya harus banyak mendekatkan diri dengan Tuhan. Spiritualitas mempunyai arti penerimaan dan kepasrahan kepada Tuhan namun disertai usaha dan ikhtiar untuk mendapatkan kesembuhan, mendekatkan diri dan meningkatkan taqwa kepada Allah merupakan strategi koping religius dengan cara mengembalikan hubungan dengan Alloh, melakukan perubahan besar pada diri sendiri setelah menderita penyakit terlebih setelah munculnya infeksi oportunistik (Andrianto1 et al., 2019). Peneliti berasumsi dengan koping religious yang baik akan memberikan dampak pemaknaan sakit positif.

\section{SIMPULAN}

Faktor infeksi oportunistik merupakan faktor dominan berhubungan dengan kemampuan menemukan makna spiritual pengalaman sakit, karena dengan adanya infeksi oportunistik mengakibatkan menurunnya kondisi ODHA secara umum, dan infeksi oportunistik merupakan penyebab kematian terbesar pada pasien HIV, seiring dengan penurunan kondisi fisik, kondisi psikologis pun menurun dengan adanya infeksi oportunistik.

Perlu menerapkan asuhan keperawatan spiritual dalam pemberian pelayanan keperawatan, perlu mengintegrasikan pendidian keperawatan yang berbasis spiritual, perlu penelitian lebih lanjut yang lebih spesifik pada responden yang baru terdiagnosa dan lama terdiagnosa karena tingkat cemas pada responden ini berbeda.

\section{REFERENSI}

Agustin, L. (2018). Hubungan antara Siritualitas Dengan Kualitas Hidup pda orang Dengan HIV/AIDS.

Amal, A. I., \& Khofsoh, E. (2018). Potret Kebutuhan Spiritual Pasien HIV / AIDS. Unissula Press, $1-5$.

Andrianto1, M. B., Mendrofa, F. A. M., \& Muin, M. (2019). Hubungan Praktek Keagamaan Islam dengan Koping Religius pada Kelompok Penderita HIV/AIDS di Wilayah Kabupaten Temanggung. 6(2), 129-133. https://doi.org/DOI:http://dx.doi.org/10.34310/jskp.v6i2.270

Anetor, G. (2019). Influence of Gender and Demographic Variables on Awareness of Secondary School Students on HIV/AIDS Infection in Abuja, Nigeria. Journal of Applied Sciences and Environmental Management, 23(1), 47. 
Jurnal Ilmu Keperawatan Medikal Bedah Vol. 4 (1), Bulan Mei Tahun 2021, Hal. 25-41 ISSN 2338-2058 (print), ISSN 2621-2986 (online)

https://doi.org/10.4314/jasem.v23i1.8

Anwar, N. (2020). Husnudon dan Penerimaan Diri pada Orang dengan HIV/AIDS (ODHA).

Aurelina, R. (2020). Faktor-Faktor yang Berhubungan terhadap Kadar Cluster of Differentiation4 (CD4) pada pasien HIV/AIDS. Medika Hutama, 02(01).

Badanta-Romero, B., de Diego-Cordero, R., \& Rivilla-García, E. (2018). Influence of Religious and Spiritual Elements on Adherence to Pharmacological Treatment. Journal of Religion and Health, 57(5), 1905-1917. https://doi.org/10.1007/s10943-018-0606-2

Beyene Gebrezgiabher, B., Huluf Abraha, T., Hailu, E., Siyum, H., Mebrahtu, G., Gidey, B., ... Angesom, T. (2019). Depression among Adult HIV/AIDS Patients Attending ART Clinics at Aksum Town, Aksum, Ethiopia: A CrossSectional Study. Depression Research and Treatment, 2019. https://doi.org/10.1155/2019/3250431

Chaiyasit, Y., Thong-on, R., Piboonrungroj, P., \& Kotta, P. (2019). the Roles of Spirituality in People Living With Hiv/Aids: a Qualitative Meta-Synthesis. The Bangkok Medical Journal, 15(1), 113-120. https://doi.org/10.31524/bkkmedj.2019.02.020

Dalmida, S. G., McCoy, K., Koenig, H. G., Miller, A., Holstad, M. M. D., Thomas, T., ... Mugoya, G. (2017). Examination of the Role of Religious and Psychosocial Factors in HIV Medication Adherence Rates. Journal of Religion and Health, 56(6), 2144-2161. https://doi.org/10.1007/s10943-017-0377-1

Guerra-pe, K., Cano-vindel, A., Adria, L., \& Herrera-martı, X. (2018). Validity and reliability of the Beck Depression Inventory ( BDI-II) in general and hospital population of Dominican Republic. 1-12.

Ilham, M., Triliana, R., \& Tilaqza, A. (2020). The Role of Age , Gender , Job , and Health Financing To Hospitalization and Secondary Infection in Hiv Patients in Malang Hospital. Jurnal Bio Komplementer Medicine, 7(1), 1-9.

Iswati, I. (2018). Karakteristik Ideal Sikap Religiusitas Pada Masa Dewasa. AtTajdid, 02(01), 58-71.

Jayani, I., \& Ruffaida, S. F. (2020). Pengaruh Pendekatan melalui Konseling Interpersonal terhadap Respon Sosial, Emosional dan Spiritual pada Pasien HIV/AIDS. Ilmiah Ilmu Kesehatan, 8(1), 62-73. Retrieved from https://jurnal.unitri.ac.id/index.php/care

Kasapoğlu, F., \& Yabanigül, A. (2018). Marital Satisfaction and Life Satisfaction: The Mediating Effect of Spirituality. Spiritual Psychology and Counseling, 3(2), 177-195. https://doi.org/10.37898/spc.2018.3.2.0048

Kemenkes RI. (2018). InfoDatin-HIV-AIDS-2018 (p. 12). p. 12.

Khusnah, H. (2019). Pengaruh Spiritualitas di Tempat Kerja, Komitmen Organisasi dan Kepuasan Kerja terhadap Kinerja Karyawan. Jurnal Ilmiah Akuntansi, 17(1), 1-121.

Kim, S., Kim, E., \& Ryu, E. (2019). Illness perceptions, self-care management, and clinical outcomes according to age-group in Korean hemodialysis patients. International Journal of Environmental Research and Public Health, 16(22). https://doi.org/10.3390/ijerph16224459

Krause, N., Pargament, K. I., \& Ironson, G. (2017). Spiritual Struggles and Health: 
Jurnal Ilmu Keperawatan Medikal Bedah Vol. 4 (1), Bulan Mei Tahun 2021, Hal. 25-41 ISSN 2338-2058 (print), ISSN 2621-2986 (online)

Assessing the Influence of Socioeconomic Status. Journal for the Scientific Study of Religion, 56(3), 620-636. https://doi.org/10.1111/jssr.12364

Lasti, M. H. (2017). Analisis Kepatuhan Minum Obat Anmtiretriviral (ARV) pada Komunitas LSL (laki-Laki Sex dengan Laki-Laki) di Kota Parepare Sulawesi Selatan. In Journal of Chemical Information and Modeling. https://doi.org/10.1017/CB09781107415324.004

Lin, Y. C., Dhaliwal, J. S., Kong, A. Z. H., Chan, L. G., \& Tan, P. L. L. (2017). HIV-related stigma as perceived by HIV-positive individuals in Singapore. HIV \& AIDS Review, 3(3), 176-182. https://doi.org/10.5114/hivar.2017.70711

Mahaendriningtiyastuti, Erna Rahma Yani, S. (2018). Stigma Dan Diskriminasi Serta Strategi Koping Pada Orang Dengan Hiv/Aids Dikota Ambon. Global Health Science, 3(1), 339-345.

Meliala, A. R. B. (2018). Perbedaan Simtom kecemasan dan depresi pada Mahasiswa kedokteran Universitas Muhammadiyah Sumatera Utara Angkatan 2014 dan 2016 dengan menggunakan The Beck Depression Inventory II dan The Back Anxiety Inventory.

Mukti, A., Nasution, A.S. \& Lubis, S. . (2019). Peran Pendidikan Agama Islam Dalam Menghempang Perilaku Lesbian Gay Biseksual Transgender di Kota Medan. Attazakki, 3(1), 143-159. Retrieved from http://www.jurnal.uinsu.ac.id/index.php/attazakki/article/view/4875

Nasasira, B., Ndichu, A., Muiru, W., Link, C., Okello, S., Nasasira, B., ... Muyingo, A. (2018). Validity and Reliability of a Self-Reported Measure of Antihypertensive Medication Adherence in Uganda The Harvard community has made this article openly available. Please share how this access benefits you . Your story matters . Citation Accessed Validi. Plos One, 11(7), 1-11. https://doi.org/10.5061/dryad.jd61j.Funding

Prasojo, D. (2017). Peran Religiusitas Pada Penderita HIV dan AIDS Yang Mengalami Depresi. Jurnal Studia Insania, 5(1), 46-70. https://doi.org/10.18592/jsi.v5i1.1270

Purwandari, Nila, P., Johan, A., \& Sujianto, U. (2019). Pengalaman Interaksi Sosial Orang dengan HIV dalam Menghadapi Stigma Sosia HIV/AIDS. Retrieved from http://eprints.undip.ac.id/76217/

Roger, K. S., \& Hatala, A. (2018). Religion, spirituality \& chronic illness: A scoping review and implications for health care practitioners. Journal of Religion and Spirituality in Social Work, 37(1), 24-44. https://doi.org/10.1080/15426432.2017.1386151

Saktina, P., \& Satriyasa, B. (2017). Karakteristik Penderita Aids Dan Infeksi Oportunistik Di Rumah Sakit Umum Pusat Sanglah Denpasar Periode Juli 2013 Sampai Juni 2014. E-Jurnal Medika Udayana, 6(3), 1-6.

Sari, N. K. (2020). Dinamika Perkembangan Spiritualitas dan Relevansinya terhadap Pendidikan Islam. 8, 53-65.

Sarkar, T., Karmakar, N., Dasgupta, A., \& Saha, B. (2019). Stigmatization and discrimination towards people living with HIV/AIDS attending antiretroviral clinic in a centre of excellence in HIV care in India. International Journal of Community Medicine And Public Health, 6(3), 1241. https://doi.org/10.18203/2394-6040.ijcmph20190619 
Jurnal Ilmu Keperawatan Medikal Bedah Vol. 4 (1), Bulan Mei Tahun 2021, Hal. 25-41 ISSN 2338-2058 (print), ISSN 2621-2986 (online)

Sarvasti, D. (2020). Pengaruh Gender dan Manifestasi kardiovaskuler pada Covid-19. https://doi.org/10.30701/ijc.1004

Syahrina, I. A., \& Pranata, ade yuda. (2018). Stigma Internal Hubungannya dengan Interaksi Sosial Orang dengan HIV/AIDS di Yayasan Taratak Jiwa Hati Padang. Jurnal Fakultas Psikologi Universitas Wisnuwardhana Malang, 22, 117. Retrieved from file:///C:/Users/Administrator/Downloads/98-Article Text-171-1-10-20181114.pdf

Umah, K., \& Irawanto, D. (2019). Motivasi Spiritual Meningkatkan Kepatuhan Minum Obat ARV pada Pasien HIV / AIDS ( Spiritual Motivation to Improve ARV Drug Compliance in HIV / AIDS Patients ). Journal of Ners Community, 10(2), 251-263.

UNAIDS. (2019). UNAIDS DATA 2019.

Wicaksono, Y. A., Fitrikasari, A., Sofro, M. A. U., \& Peni, H. (2018). Hubungan Stigma dan Terapi ARV dengan Komplikasi Gangguan Psikiatri pada Pasien HIV/AIDS. Jurnal Penyakit Dalam Indonesia, 5(1), 24. https://doi.org/10.7454/jpdi.v5i1.161.

Widianti, E. (2018). Tingkat Kecemasan terhadap Kematian pada ODHA. Jurnal $\begin{array}{lll}\text { Keperawatan Soedirman, } & 199 .\end{array}$ https://doi.org/10.20884/1.jks.2017.12.3.758

Yuliyanasari, N. (2017). Global Burden Desease - Human Immunodeficiency Virus Acquired Immune Deficiency Syndrome ( HIV-AIDS ). (October 2016), 65-77. 